\title{
Landscapes of Northern Lombardy: from the glacial scenery of Upper Valtellina to the Prealpine lacustrine environment of Lake Como
}

\author{
Irene Bollati ${ }^{(1)}$, Manuela Pelfini ${ }^{(1)}$ and Claudio Smiraglia ${ }^{(1)}$ \\ ${ }^{(1)}$ Dipartimento di Scienze della Terra, Università degli Studi di Milano, Via Mangiagalli 34, 20133 Milano, \\ Italy \\ corresponding author: Irene Bollati <irene.bollati@unimi.it>
}

\begin{abstract}
In the region between Valtellina and Lake Como in the Central Italian Alps, one can visit, in a relatively small area, some of the best examples of mountain geomorphological landscapes of Italy. Eight specific sites, showing peculiar glacial, periglacial, structural, gravity-induced and erosional landforms, have been selected to illustrate how different landscapes may originate from geomorphological modelling of different lithotypes in different morphogenetic systems. These eight sites are exemplary cases in which significant evidence of past and current climatic and structural conditions characterising this region is exhibited.
\end{abstract}

\section{Keywords}

Glacial landscape, periglacial landscape, structural landscape, Valtellina, Lake Como

\section{Introduction}

The Central Italian Alps and the related Prealpine areas are characterised by different structural domains of the Alpine range and by different climatic conditions. As a consequence, a succession of various landscapes and landforms related to the lithological and structural complexity of the Alpine region characterises this territory; changes in landforms modelled under different geological and climatic conditions are observable within a region spanning just a few kilometres.

The outcropping lithotypes behave differently with respect to chemical and mechanical weathering and, especially in the Alpine high mountain environment, surface processes are subject to variations in intensity as a consequence of climate change. In this sense, the high mountain environment allows us to directly observe landscape responses to the current climatic trend. The upper sector of Valtellina is characterised by the presence of the most sensitive indicators of climate change - glaciers, some of which are among the most important in the Alps, such as the Forni glacier, which is the widest valley glacier of the southern side of the Alps. At higher altitudes, the temporal and spatial transition from a glacial to a paraglacial system is documented by glacier shrinkage and widening of proglacial areas. In the meantime, gravity-driven processes, water runoff and periglacial processes are intensifying in the Alpine environment. These changing dynamics are also a crucial for hazard and risk assessment, and for promotion and conservation of geomorphological heritage, especially concerning glaciers and depositional landforms such as moraines (Pelfini and Bollati 2014).

Moreover, in Valtellina the rock-landform relationships are various and peculiar: the Oligocene calcalkaline rocks of the Masino and Mello Valleys and the ophiolitic rocks outcropping in Valmalenco are modelled to produce relief in significant contrast to each other.

Last but not least, the presence of important structural lineaments (i.e., the Insubric Line) has significantly influenced the trend of the valleys, in particular the main valley, Valtellina, which has a clear E-W trend from Tirano to Colico.

Within the Central Italian Alps, from Upper Valtellina to the Lake Como area, eight sites/landscapes were selected. Some of them are included in the National and/or Regional Database of Geosites and others host cultural and nature trails or thematic. In Table 1, codes used in the Geosites list of the Regional Geoportal of 
Lombardy are reported. The sites are numbered following a geographical order from the Upper Valtellina as far as Lake Como and they are presented in the text following a set of geological-geomorphological criteria.

\section{Geographical setting}

The area is located in the Central Italian Alps (Fig. 1b), in the Rhaetian sector, principally along the Adda Basin and Valtellina valley, within the provinces of Sondrio, Lecco and Como, generally following National Roads 36 and 38 (Fig. 1a). The area includes several elevated peaks of the Central Italian Alps, among which are the Disgrazia (3,678 m a.s.1.) and the Bernina $(4,049 \mathrm{~m})$ in the Bernina Group, and the peaks of Gran Zebrù $(3,857 \mathrm{~m})$, Cevedale $(3,679 \mathrm{~m})$ and San Matteo $(3,678 \mathrm{~m})$ in the Ortles Cevedale Group. In the Upper Valtellina, the inter-regional Stelvio National Park was instituted in 1935, and its Lombardy sector covers a surface area of $593 \mathrm{~km}^{2}$. It includes one of the most important glaciers of the Italian Alps: the Forni Glacier (Fig. 1a). Lake Como, which runs along the area between the Alps and the Brianza region, has a surface of $144 \mathrm{~km}^{2}$. It splits halfway into two branches, the Como and Lecco branches, in the middle of which the Triangolo Lariano region is located (Fig. 1a).

\section{Geological and geomorphological landscapes}

The Valtellina and Lake Como areas belong to different Alpine structural domains: Austroalpine, Pennidic and Southern Alps (Fig. 2a). The Upper Valtellina, in the northeastern part, is characterised by outcrops of different nappes of the Austroalpine Domain that represent the remnants of the paleo-African continent. The bedrock of the Valmalenco area, located north of Sondrio, is constituted by rocks belonging to the paleo-African Austroalpine Nappes and to the oceanic and paleo-European Pennidic Nappes. A portion of Sissone and of the nearby Masino and Mello valleys is also characterised by outcrops of the Oligocene pluton of Masino-Bregaglia (Bergell), the emplacement of which is linked to Tertiary magmatic activity, and which developed during the late Alpine orogenesis stages.

The Periadriatic Fault System (i.e., the Insubric Line), with a local E-W trend, marks the contact of the Austroalpine and Pennidic Domains with the Southern Alps Domain, and represents the separation mark between the Alps sensu strictu and the Southern Alps region.

Part of the Southern Alps Domain in the area consists of sedimentary rocks such as Triassic limestones and siliciclastic deposits of sedimentary cover that lie above the paleo-African basement. A complete section of this succession is visible along the eastern side of Lake Como, where National Road 36 runs.

The different lithologies have been moulded by different physical agents (e.g., gravity, water, ice, wind) for thousands of years, and structural landscapes are evident in the region. Glaciers represent one of the most active landscape modelling factors from the highest peak regions to as far as Lake Como. During the Last Glacial Maximum (LGM; 30,000-15,000 years BP), the main glaciers flowing from Valtellina and Chiavenna Valley split into different lateral glaciers and reached the Brianza region (Fig. 2b), as evidenced by the presence of huge moraine amphitheatres (Bini and Zuccoli 2004). Recent glacial landforms characterise the higher altitudes in the region. The periglacial landscape, symbolised by rock glaciers, is widespread over the Upper Valtellina, and active and well-preserved landforms are common in the Livigno and Foscagno areas.

\subsection{The glacial landscapes of the Forni Valley}

In the Upper Valtellina, the most important Italian valley glacier is present: the Forni Glacier (Fig. 1a, 3), with a surface area, in 2007, of $11.36 \mathrm{~km}^{2}$ (D'Agata et al. 2014) and an elevation range today between 3,670 $\mathrm{m}$ and 2,500 $\mathrm{m}$. It is located in the Ortles-Cevedale Group, within the Stelvio National Park. The area is characterised by an outcrop of low-grade metamorphic basement of the Bormio Phyllades of the Austroalpine Nappe. They are in contact, in the head of the northeastern tributary valley, with limestones and dolomites of sedimentary cover that forms the pyramid of Gran Zebrù, which stands out prominently. 
The Forni Glacier has undergone visible shrinkage, as evidenced by comparison of glacier front positions between the $19^{\text {th }}$ and the $21^{\text {st }}$ centuries (Fig. 3a, b). As quantified recently by D'Agata et al. (2014), the whole glacial surface area of the Ortles-Cevedale Group has undergone surface area changes of $-19.43 \mathrm{~km}^{2} \pm 1.2 \%$, or approximately $-40 \%$, in the interval from 1954 to 2007 , with an accelerated surface reduction of approximately $8.7 \%$ between 2003 and 2007. This equates to an area loss of approximately $0.693 \mathrm{~km}^{2} /$ year. The glacier thickness, where locally covered by debris, is higher as a result of differential ablation. On the glacial surface there are spectacular active medial moraines and active bédières that are streamflows draining the surface of the glacier.

The Forni Valley represents a typical glacial U-shaped valley (Fig. 3a, b) with huge and abundant roche moutonnée and active or relict giant kettles (Fig. 3e). The records of several fluctuations are well documented and preserved by the numerous moraine ridges characterising the valley floor and slopes. The Late Glacial lateral moraines (locally dated 11,000-10,000 years BP) are well developed and conserved along the south and SW-facing slopes, with thick soil coverage. The Holocene and historical moraines are well expressed and are characterised by different levels of development of soil, vegetation coverage and lichen colonisation in relation to their exposure age, and they are easily observable all along the glaciological trails (Fig. 3c, d) (Orombelli and Pelfini 1985).

The maximum advance of the Forni Glacier during the Holocene is evidenced by remnants of a terminal moraine that has an age close to that of the Little Ice Age (LIA). It dams a small peat bog radiocarbon dated to $2670 \pm 130$ years $\mathrm{BP}{ }^{14} \mathrm{C}(830-710 \mathrm{cal}$ years $\mathrm{BC})$, which represents the minimum age for the glacier's advance (Orombelli and Pelfini 1985). The main advance and retreat phases of the Forni Glacier tongue after the LIA, evidenced by moraine ridges, happened at the beginning of the $20^{\text {th }}$ century: 1904 or 1913-1914, 1926. During the next retreat phase the Forni glacial basin underwent separation into different minor glaciers. The neo-formational moraines resulting from the most recent 1974-1981 advance phase are unconsolidated, dissected by the action of the proglacial stream and largely affected by weathering processes and physical degradation due especially to the melting of the ice core (Pelfini and Bollati 2014).

\subsection{Periglacial landscape: the rock glaciers of Foscagno Pass}

Periglacial features (i.e., rock glaciers, protalus ramparts, polygonal and striated soils) are quite widespread, especially in the Upper Valtellina area, and several examples of these landforms have been studied since the 1980s. In the Foscagno area (Fig. 1a), periglacial landforms and especially rock glaciers are dominant, providing one of the best expressions of periglacial landscapes. The presence of deformed and fractured schist and paragneiss allow, in this climate, for the formation of a great quantity of debris indispensable for the genesis of rock glaciers. The rock glaciers are both active and inactive: in the first case the fronts are generally located at an elevation of 2,600 m; in the second case they are located below 2,500 m altitude. The quantification of permafrost in the Foscagno area also allowed for recognition of its patchy distribution within the rock glaciers; the active layers range from 1.2 to $1.5 \mathrm{~m}$ (N-facing slopes) to almost 10 $\mathrm{m}$ (SE-facing slopes) (Guglielmin et al. 1994).

The Forcellina cirque and the below area of Vallaccia are occupied by the Foscagno rock glacier (Fig.4), which is the most important and the most-studied rock glacier of the Italian Alps. It can be approached from National Road 38 (Fig. 1a). It has a multi-lobed structure and exhibits typical rock-glacier debris zoning. It develops for approximately $1 \mathrm{~km}$ and the active zone front is located at a lower altitude than others in this area $(2,500 \mathrm{~m})$. The ice is considered a relic of glacier ice preserved within a permafrost body that flowed down to the current position from the Forcellina cirque area (Guglielmin et al. 2004).

\subsection{The Val Pola rock avalanche: a dramatic change in the landscape}

Gravity-induced processes are very frequent in the upper Valtellina. The most catastrophic event occurred on $27^{\text {th }}$ July 1987 and radically changed the local landscape by burying a small village and damming the Adda River's course. 
During the months of July and August 1987, a serious flood emergency developed, due mainly to intensification of heavy rain. Between 15-22 July 1987 exceptionally warm temperatures and rainfall exceeding half of the mean annual precipitation for this area (i.e., 1,200 mm) were recorded (Crosta et al. 2004). Numerous landslides and debris flows occurred during this period in the Upper Valtellina; among these the most dangerous was the Val Pola rock avalanche which is still observable from the older road built to cross the landslide (Figs. 1a; 5). The landslide deposit has been progressively modified by both natural surface processes and human activities undertaken for risk management and for restoration of safe access.

The Val Pola landslide detached from the eastern slope of Mount Zandila, which consists of Austroalpine Domain rocks such as gneisses intruded by diorite and gabbros, and which was characterised by a prehistoric landslide located at the intersection of two major joint sets. Between 18-19 July 1987 debris flows moved down the slope, damming the Adda River and causing the formation of a lake with an estimated volume of $50,000 \mathrm{~m}^{3}$ and a depth of $1-5 \mathrm{~m}$. In the following days, several fractures along the prehistoric scarp were observed, and on the $27^{\text {th }} \mathrm{July}$, the Val Pola rock avalanche occurred. The landslide volume was estimated at approximately $40 \mathrm{Mm}^{3}$. The debris reached as far as 1,200 m below the landslide scarp, running $300 \mathrm{~m}$ up on the opposite side of the valley, and material was distributed both up- and down-stream along the Adda River (Fig. 5). This landslide is considered to be among the most rapid mass movements ever documented (76 to $108 \mathrm{~m} / \mathrm{s}$ ) (Crosta et al. 2004), and the rock avalanche, entering the debris-dam lake that had formed in the previous days, produced an anomalous water wave. Significant topographic changes occurred, numerous buildings were destroyed and twenty-seven people were killed. The modelling of the Val Pola landslide based on run-out extent, debris profiles, velocities and deposition distributions (see Crosta et al. 2004) provides us with the opportunity to better understand this type of hazard which may significantly affect alpine valleys.

\subsection{Postalesio earth pyramids: the modelling of glacial deposits by runoff}

Coming from the Upper Valtellina, the landscape shows a transition from landforms shaped mainly by glaciers to polygenic landforms generated by mass wasting and fluvial action.

The Postalesio earth pyramids, located a few kilometres west of Sondrio (Figs. 1a; 6), are famous landforms in Upper Pleistocene glacial deposits, where gneiss and micaschist boulders of the Tonale Units are incorporated and protect the finer portion of the deposit from runoff. Water runoff action is the main process which shapes the deposits of different grain size into spectacular forms. The pyramids have been evolving, and both the formation of new pyramids and the dismantling of old ones is deduced by the presence of fallen blocks at the base of the slopes. In Fig. 6, a shot of the pyramids in 1931, as included in the monograph "The Alps" by Federico Sacco (1934), is compared with the current situation, and at least seven pyramids are easily distinguishable. The path that allows a visit along the perimeter of this Natural Reserve has recently been buried by sediment due to heavy rainfall that occurred during the autumn of 2013.

\subsection{The lithological landscapes of Valmalenco and Masino Valleys}

During the Oligocene, a regional tensional regime led to the emplacement of several wide plutons distributed mainly along the Insubric Line. One of the most important plutons is located on the northern side of Valtellina and is known as Masino-Bregaglia or Bergell Pluton (Fig. 1a). It develops in the area between Valmalenco (Sissone Valley, in the western part) and Chiavenna Valley, with a tail that reaches the Bellinzona area, and covers an area of approximately $280 \mathrm{~km}^{2}$. The pluton is characterised by elongation along the Insubric Line. The calk-alkaline lithotypes that characterise the pluton are of two types: on the southern and southeastern edges of the pluton, fine grained tonalite is present (locally named "Serizzo"), while the core and the eastern portion of the pluton consist of a large-feldspar granodiorite that, because of the presence of porphyroclasts of potassium feldspar, is known locally as "Ghiandone".

Morphology of the granitic pluton has been shaped by advancing glaciers and by their recent retreat, and also by gravity-driven processes, particularly after the LGM which have produced voluminous rock fall deposits. Running water and fluvial action have been playing an important role in modelling this landscape 
to a considerable extent as a typical example of a lithological landscape. The Masino and Mello Valley sides are famous for the awe-inspiring rock walls. In the Masino Valley near San Martino, one of the most impressive and famous mega-boulders, the Sasso Remenno, which has a volume of several hundred cubic metres, is present as the result of a huge rock fall (Crosta 1994).

Due to the valley shape and the quality of the granite lithotype, large numbers of tourists and climbers visit the area, especially during summer. Climbing on the rock walls of Mello Valley or on the Sasso Remenno is an appreciated activity, and the granitic walls of the Masino and Mello Valleys are famous all over Europe as "the little Yosemite". One of the most important mountains in the Masino Valley area, approachable from both the Swiss and Italian sides, is the Badile Peak, a beautiful example of modelling on granite substrate.

From a geological point of view, the area near Valmalenco is significant because along the valley it is possible to cross the different tectonic units of the paleo-African Austroalpine Nappes and oceanic and paleo-European rocks of the Pennidic Nappes. The importance of Valmalenco is also attributable to mining activity, deriving from the presence of many types of minerals such as chromite, asbestos and manganese nodules that are exported all over the world.

In the mountainsides surrounding Chiareggio village (Figs. 1a; 7) in the Sissone Valley, the panoramic view of contrasting lithological landscapes is meaningful (Fig. 7): the contact is evident between the Oligocene intrusive rocks and the ultramafic rocks of the ophiolitic Malenco-Forno Nappe that makes up the Disgrazia Peak and others. The names of the peaks in the area (i.e., Sasso Nero and Sasso Moro) reflect the dark colour of the unweathered ultramafic lithotypes, and the same naming pattern is evident where the weathering of the ferric serpentinite rocks gives them a very red aspect (i.e., Preda Rossa, Corna Rossa, and Corni Bruciati).

Many itineraries and hiking trails allow enjoyment of these spectacular landscapes, which range from lithological to glacial.

\subsection{The lacustrine landscape of Lake Como}

Lake Como collects, in the northern sector, the waters of the Mera River flowing from the Chiavenna Valley and of the Adda River flowing from Valtellina (Figs. 1a; 8). In this region, a wide plain area, the Pian di Spagna, gradually develops and consists of alluvial deposits of both rivers, though the Adda River sedimentation rate has been the most influential one. In fact the advance of sedimentation towards the west led to the progressive separation of Lake Como, in historical times (around the $16^{\text {th }}$ century), from the Mezzola Lake located to the north in the Chiavenna Valley. The Pian di Spagna, an internationally recognised wetland, derives its name from Spanish rule during the $17^{\text {th }}$ century.

From National Road 36, it is possible to appreciate the Lake Como landscape. The current Lake Como basin shape is an inverted "Y" where the towns of Como and Lecco are located on the two southern tails (Figs. 1a; 8). Along the lake sides, from north to south, the change from metamorphic basement to the Permo-Mesozoic sedimentary cover of the Southern Alps is visible.

During the period between the Oligocene and the Middle Miocene, renewed tectonic activity accompanied by a rapid orogenic uplift activated the Alps, and in the final phase of the Miocene, during the Messinian (7.2-5.3 Ma BP), the closure of the connection between the Atlantic Ocean and the Mediterranean Sea led to the complete desiccation of the Mediterranean Sea, with the consequent deposition of hundreds of kilometres of evaporite deposits. This episode played a fundamental role in the formation of Lake Como and the other large Prealpine Lakes such as Lake Maggiore and Lake Iseo, for example. This event led to an irregular increase of the incision level of the rivers, mainly N-S oriented such as the Adda River, that tended to reach the new, lower elevation. The most important consequence of this incision was the formation of deep canyons along the Mediterranean margins. Southern Alpine lakes generally have common features such as N-S orientation, steep lateral slopes and lakebeds that lie below sea level (i.e., cryptodepressions), confirmed by geophysical investigations conducted in both the Po Plain and Lake Como. According to these 
studies a possible link between lake formation, intensification of erosion and the formation of canyons has been proposed (Bini et al. 1978).

At the end of the Pleistocene, in the LGM phase, the glaciers present in the area were locally up to $2 \mathrm{~km}$ thick, leaving only the higher peaks exposed above the ice (Cavallin et al. 1997). These constituted a complex system of valley glaciers continuing south from the main glaciers coming out of the Valtellina and Chiavenna valleys, and forming the piedmont glaciers of Como, Brianza and Lecco (Fig. 2b). The glaciers left, as a record of their maximum expansion, a series of concentric moraine ridges referred to as the moraine amphitheatres of Brianza and Lecco. The characteristics of medial and end moraines, together with the positions of erratic boulders and glacial deposits in caves, permitted the reconstruction of thirteen glacial episodes in the Prealpine area since the Late Pliocene (Bini et. al. 1996). The erratic boulders dispersed in the area down valley of Lake Como are representative of the outcropping lithotypes in the broad provenance basin of the Adda River, among which the previously described granitic and ultramafic rocks of the Valmalenco and Masino Valley are widely represented. Some of these erratic boulders, which have names linked with local traditions (e.g., Sass Negher, Pietra Luna and Pietra Pendula), are now protected as natural monuments.

Hence, the glacial modelling of the prior canyons, previously proposed as the primary agent for the formation of the U-shaped steep flanks of Lake Como's profile, might have acted only in a secondary manner, remodelling the canyons and partially re-eroding the sediments pertinent to the Messinian desiccation events and to the successive Pliocene transgression phase.

\subsection{The karst landscape of the Grigne Massif}

Approaching the Lake Como area, where calcareous lithotypes become dominant, karst landforms are widespread. One of the most representative and well known karst landscapes of the Central Italian Alps develops in the Grigne Massif, located on the eastern side of Lake Como (Figs. 1a; 8). The area is characterised by the sedimentary cover of the Southern Alps which lies above the metamorphic basement outcropping towards the north. The Triassic limestones of the Grigne Massif belong mainly to the Esino dolomitic limestone Platform (Upper Anisian - Ladinian), which forms the two most important peaks: the Northern Grigna $(2,399 \mathrm{~m})$ and the Southern Grigna $(2,181 \mathrm{~m})$. The landscape is typically characterised by karst landforms, especially along the Bregai edge: dolines, shafts, hills, flat rock surfaces and karren (microkarsts) are represented. Snow is present in the area for several months of the year. In the past, the soil coverage must have been very thick, as covered karst landforms are widespread (Santilli et al. 2005).

Different paleo-karst stages led to the formation of a broad and deep karst system that has been successively cut by Quaternary glacial erosion. In fact, the area is renowned from a speleological point of view, and in some of these caves ice is still present, as reported by Leonardo Da Vinci, who was among the first to note this feature. Among the deepest and most famous caverns there is the "Abisso W le Donne" (1,160 m deep). The ice from one of these caves ("Abisso sul Margine dell'Alto Bregai”, $192 \mathrm{~m}$ deep) has been analysed for $\delta^{18} \mathrm{O}$ and ionic content relative to depth; the ice is considered to be derived from the crystallisation, from the top to the bottom, of lake water, with partial opening of the system and entry of different sources of water (Citterio et al. 2004).

Also around the Grigna Massif are interesting hiking trails; the one that reaches the Northern Grigna peak from Esino Lario and that crosses the most important cave areas allow observation of the geomorphological features of the area.

\section{Conclusions}

The Central Italian Alps, and in particular the region between Upper Valtellina and Lake Como, permit observation of a varied series of landforms and landscapes by following the retreat path of the glaciers since the LGM. The different structural domains of the Alps are reflected in the various lithological patterns, and the differentiation of geomorphological processes acting through time and space allows us to make 
inferences regarding the influence of climate change on the intensity and frequency of climate-related processes. The records of the most important evolutionary phases of the Alpine range are present and comprehensible within the current landscapes, as is the glacial evolution from the maximum extent during the Upper Pleistocene until the Little Ice Age, and the current shrinkage phase.

\section{The Authors}

Irene Bollati is a Post-Doctoral Scientist at the Earth Science Department "A. Desio" of Università degli Studi di Milano. She works on geoheritage and geomorphological processes affecting active geomorphosites through the integration of geomorphological and dendrogeomorphological techniques and on the dissemination of Earth Sciences. Her main study areas are located in the Western and Central Italian Alps, the Northern Apennines and the Swiss Alps.

Manuela Pelfini is a full Professor of Physical Geography and Geomorphology at the Earth Science Department "A. Desio" of Università degli Studi di Milano. She works on the spatio-temporal evolution of landscapes as a response to climate change, especially in the high mountain environment. Her research includes landscape valorisation, geomorphological hazards related to mountain tourism, and dendrogeomorphology. Her study areas are located in the Italian Alps and Apennine chains.

Claudio Smiraglia is a full Professor of Physical Geography and Geomorphology at the Earth Science Department "A. Desio" of Università degli Studi di Milano. He works in the field of glacial and periglacial geomorphology, glaciology and climatology, rock glaciers and the recent dynamics of high mountain environments. In addition to study sites located mainly in the Central and Western Italian Alps, he has taken part in scientific expeditions to glaciers on different continents (Africa, Asia, South America, and Antarctica).

\section{References}

Bini A, Cita MB, Gaetani M (1978) Southern Alpine lakes - Hypothesis of an erosional origin related to the Messinian entrenchment. Marine Geology 27(3): 271-288

Bini A, Felber M, Pomicino N, Zuccoli L (1996) Maximum extension of the glaciers (MEG) in the area comprised between Lago di Como, Lago Maggiore and their respective end-moraine system. Geologia Insubrica 1(1): 65-78

Bini A, Zuccoli L (2004) Glacial history of the southern side of the central Alps, Italy. In: Ehlers J, Gibbard PL, Hughes PD (eds) Quaternary Glaciations. Extent and Chronology. Elsevier, London: 195-200

Cavallin A, Baroni C, Bini A, Carton A, Marchetti M, Orombelli G, Pelfini M, Zanchi A (1997) Geomorphology of the Central and Southern Alps. Supplementi Geografia Fisica Dinamica Quaternaria III(2): 13-47

Citterio M, Turri S, Bini A, Maggi V (2004) Observed trends in the chemical composition, $\delta 180$ and crystal sizes vs. depth in the first ice core from the "LoLc 1650 Abisso sul Margine dell'Alto Bregai" ice cave (Lecco, Italy). Theoretical and Applied Karstology 17: 27-44

Crosta G (1994) An example of unusual complex landslide: from a rockfall to a dry granular flow. Geologica Romana 30: 175-184 
Crosta GB, Chen H, Lee CF (2004) Replay of the 1987 Val Pola Landslide, Italian Alps. Geomorphology 60(1-2): 127-146

D’Agata C, Bocchiola D, Maragno D, Smiraglia C, Diolaiuti G (2014) Glacier shrinkage driven by climate change during half a century (1954-2007) in the Ortles-Cevedale group (Stelvio National Park, Lombardy, Italian Alps). Theoretical and Applied Karstology 116: 169-190

Guglielmin M, Lozej A, Tellini C (1994) Permafrost distribution and rock glaciers in the Livigno Area (Northern Italy). Permafrost and Periglacial Processes 5(1): 25-36

Guglielmin M, Camusso M, Polesello S, Valsecchi S (2004) An old relict glacier body preserved in permafrost environment: The Foscagno rock glacier ice core (Upper Valtellina, Italian Central Alps). Arctic, Antarctic and Alpine Research 36(1): 108-116

Montrasio A, Bini A, Berra F, Cariboni M, Ceriani M, Deichmann N, Ferliga C, Gregnanin A, Guerra S, Gugliemin M, Jadoul F, Longhin M, Mair V, Mazzoccola D, Sciesa E, Zappone A (2012) Carta Geologica d'Italia 1:50,000. Foglio 024 - Bormio, Note illustrative. S.E.L.C.A., Firenze, 17 pp

Orombelli G, Pelfini M (1985) Una fase di avanzata glaciale nell'Olocene superiore, precedente alla Piccola Glaciazione, nelle Alpi Centrali. Rendiconti Società Geologica Italiana 8: 17-20

Pelfini M, Bollati I (2014) Landforms and geomorphosites ongoing changes: concepts and implications for geoheritage promotion. Quaestiones Geographicae 33(1): 131-143

Sacco F (1934) Le Alpi. Touring Club Italiano Ed., Milano, 736 pp

Stoppani (1876) Il Bel Paese. Barbera Ed., Milano, 682 pp

Santilli M, Pelfini M, Citterio M, Turri S (2005) Landscape history in the subalpine karst region of Moncodeno (Lombardy Prealps, Northern Italy). Dendrochronologia 23: 19-27.

\section{Figure captions}

Fig. 1 Geographical setting of the Valtellina and Lake Como area and location of the geomorphological sites described.

Fig. 2 (a) Geological setting and principal structural features of the described area (modified after Montrasio et al. 2012). (b) Reconstruction of glacier extent in the Central Alps during the LGM and the present day (modified after Cavallin et al. 1997).

Fig. 3 Glacial landscape of the Forni Valley. Comparison of the Forni Glacier during the Little Ice Age (LIA) (photo from Stoppani, 1876) (a) and the latter half of the $19^{\text {th }}$ century and the Forni Glacier during summer 2012 (photo I. Bollati, taken in 2012) (b). View of the glacial terminus and of the LIA moraine from the left hydrographic valley side (photo I. Bollati, taken in 2012). (c). View towards the Cedec Valley of the vegetation recolonisation process along the proglacial area from the left hydrographic valley side (photo I. Bollati, taken in 2012) (d). Subglacial giant kettles on the left side of the valley at 2,500 $\mathrm{m}$ a.s.l. along the upper glaciological trail (photo I. Bollati, taken in 2012) (e). 
Fig. 4 The Foscagno rock glacier. Panoramic view of the northeastern side of Monte Foscagno (photo by G. Scherini, 2010) (a). Aerial photo from 2007 (courtesy of Geoportale Nazionale - Ministero dell'Ambiente) in which the Foscagno rock glacier perimeter is shown. The white line delimits the active portion of the rock glacier, and the white dashed line borders the inactive portion, as identified by Guglielmin et al. (2004) (b).

Fig. 5 The Val Pola landslide viewed from the opposite side of the main valley (photo V. Garavaglia, taken in 2009).

Fig. 6 Postalesio earth pyramids. (a) Image extracted from Sacco (1934). (b) View of the pyramids from the lower portion of the tourism path (I. Bollati, taken in 2013).

Fig. 7 Geological landscape of granites and ophiolitic rocks in the Sissone Valley. The contact between oceanic rocks of the Valmalenco Nappe (serpentinites and amphibolites) and granites of the Val MasinoBregaglia pluton is very evident, enhanced by the contrasting colours: the red of oxidised serpentinites stands out clearly (photo M. Lucini, taken in 2009).

Fig. 8 Panoramic view of Lake Como. The Lecco branch of the lake is visible with the peaks of the Grigna Massif in the background: the Northern Grigna $(2,399 \mathrm{~m})$ and the Southern Grigna $(2,181 \mathrm{~m})$, respectively known as "Grignone" and "Grignetta". The photo was taken from the Barni village $(635 \mathrm{~m})$ located between the two branches of Lake Como (photo I. Bollati, taken in 2011).

Table 1 Summary table of the described sites and landscapes. The reference code and the scientific interest are from Geoportale Regione Lombardia. 

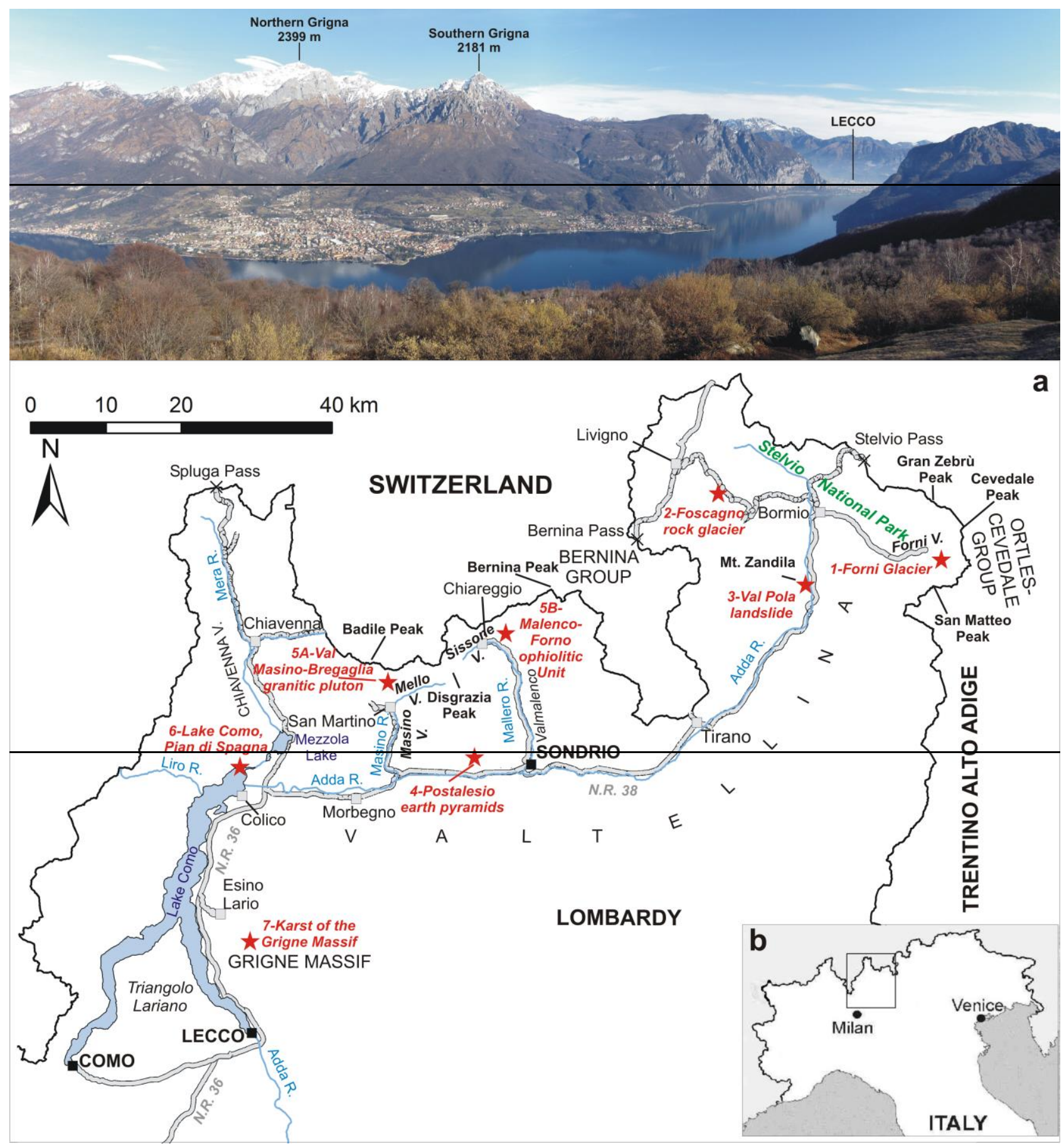


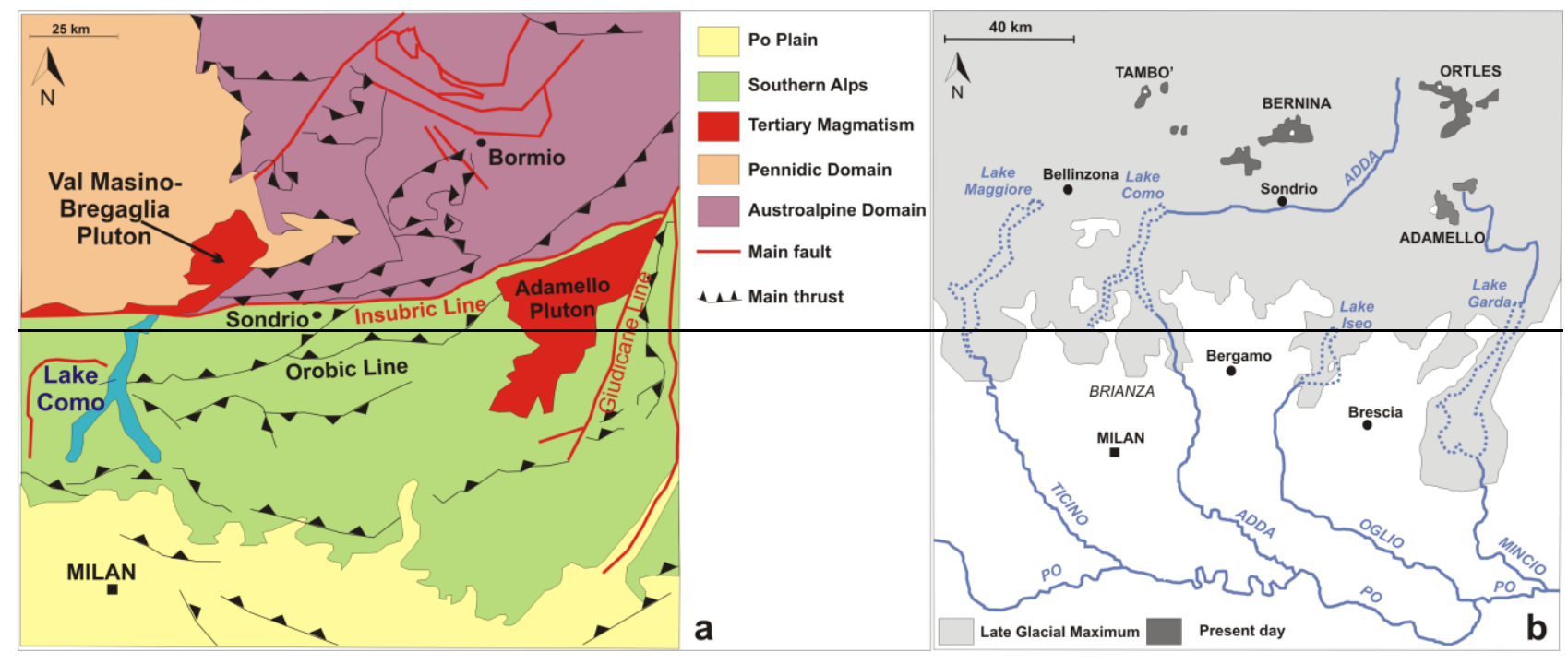




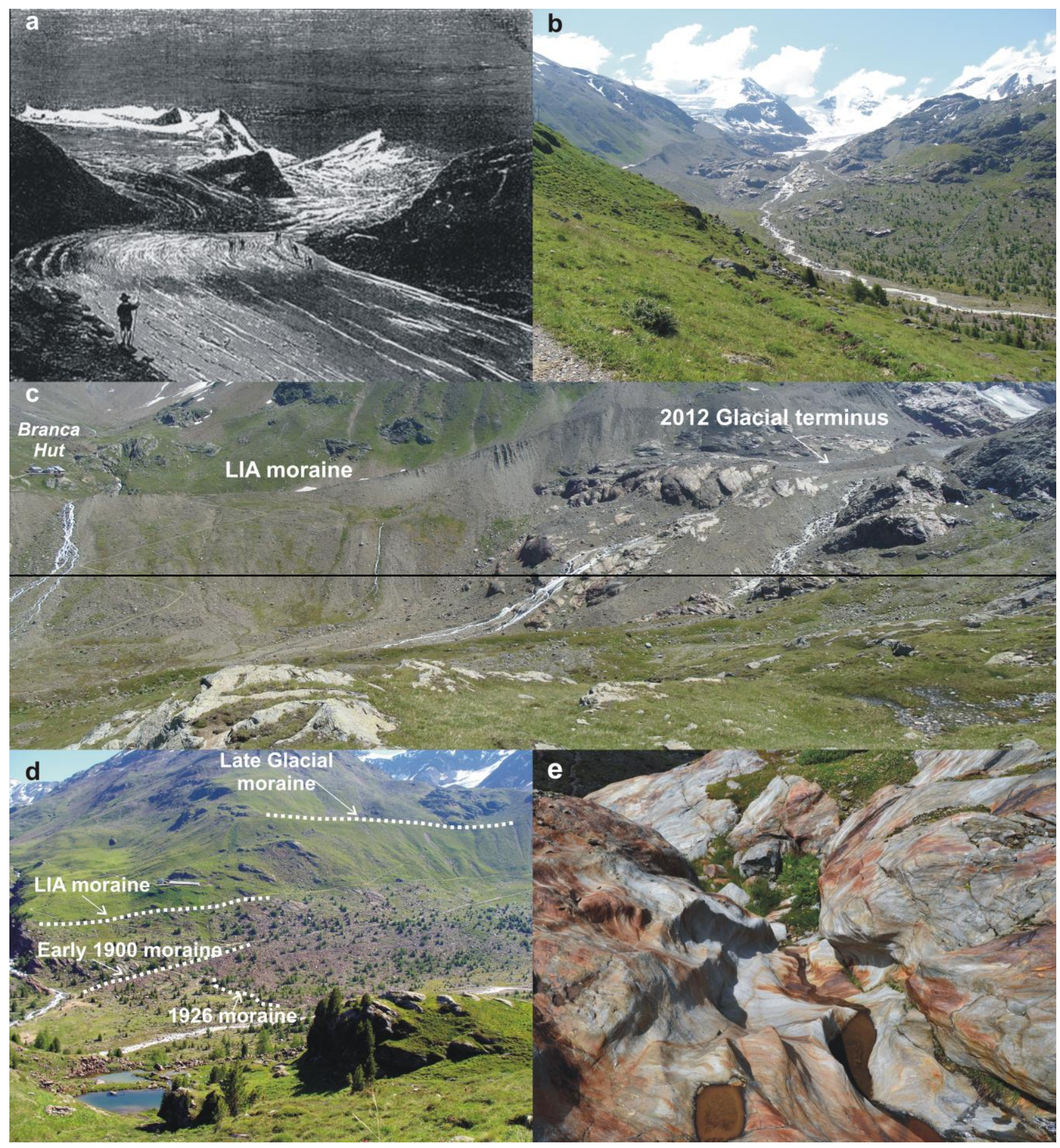



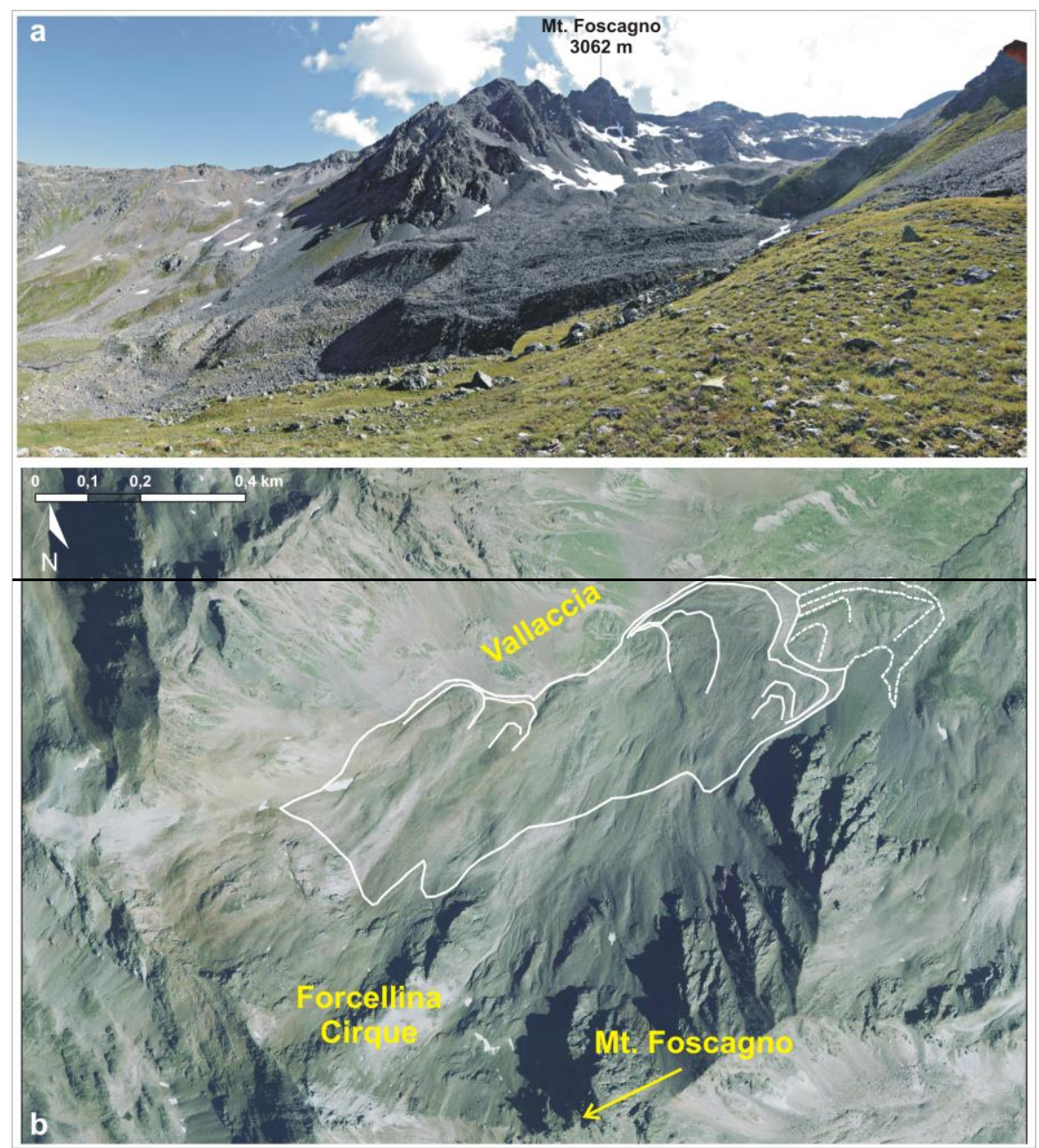


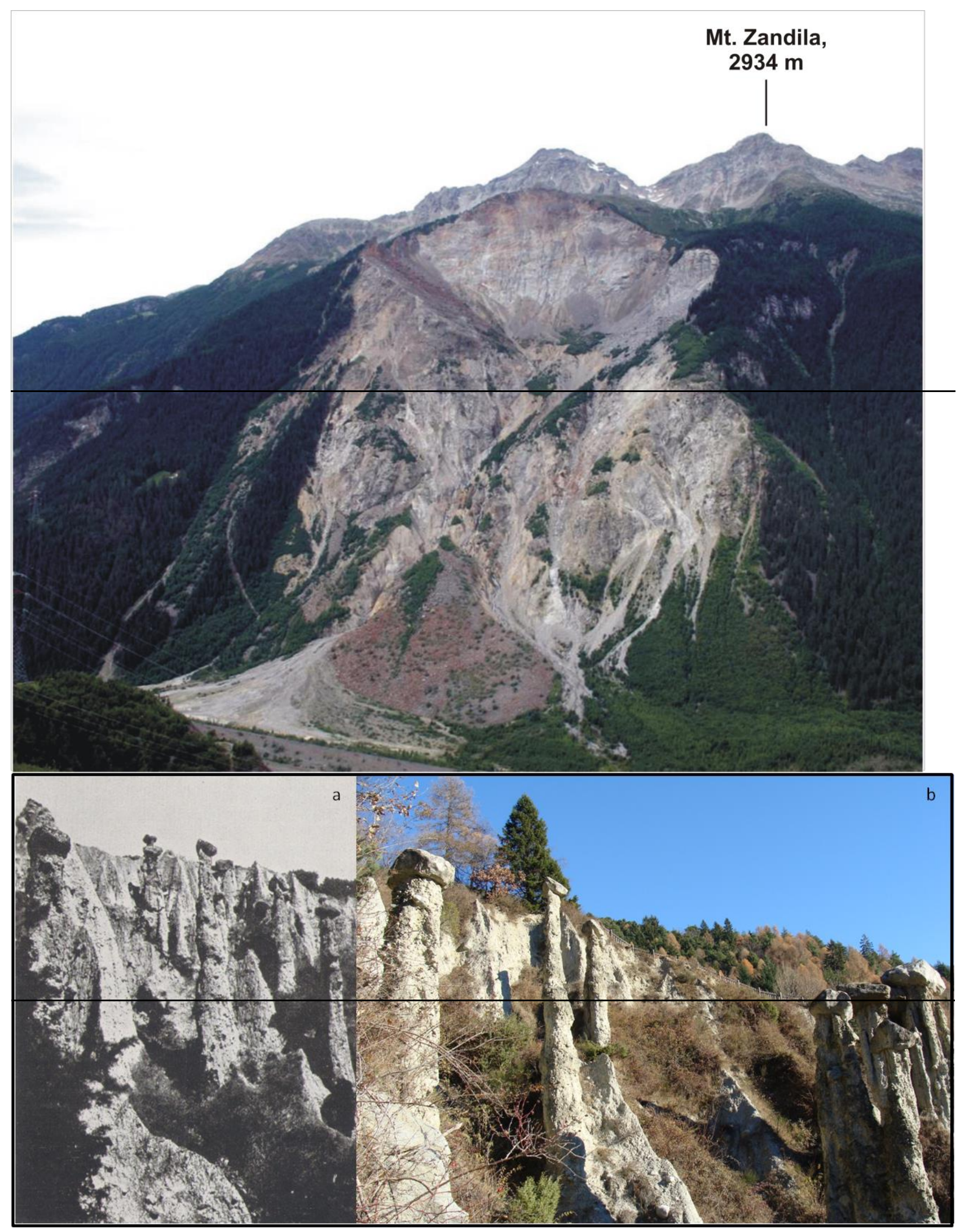




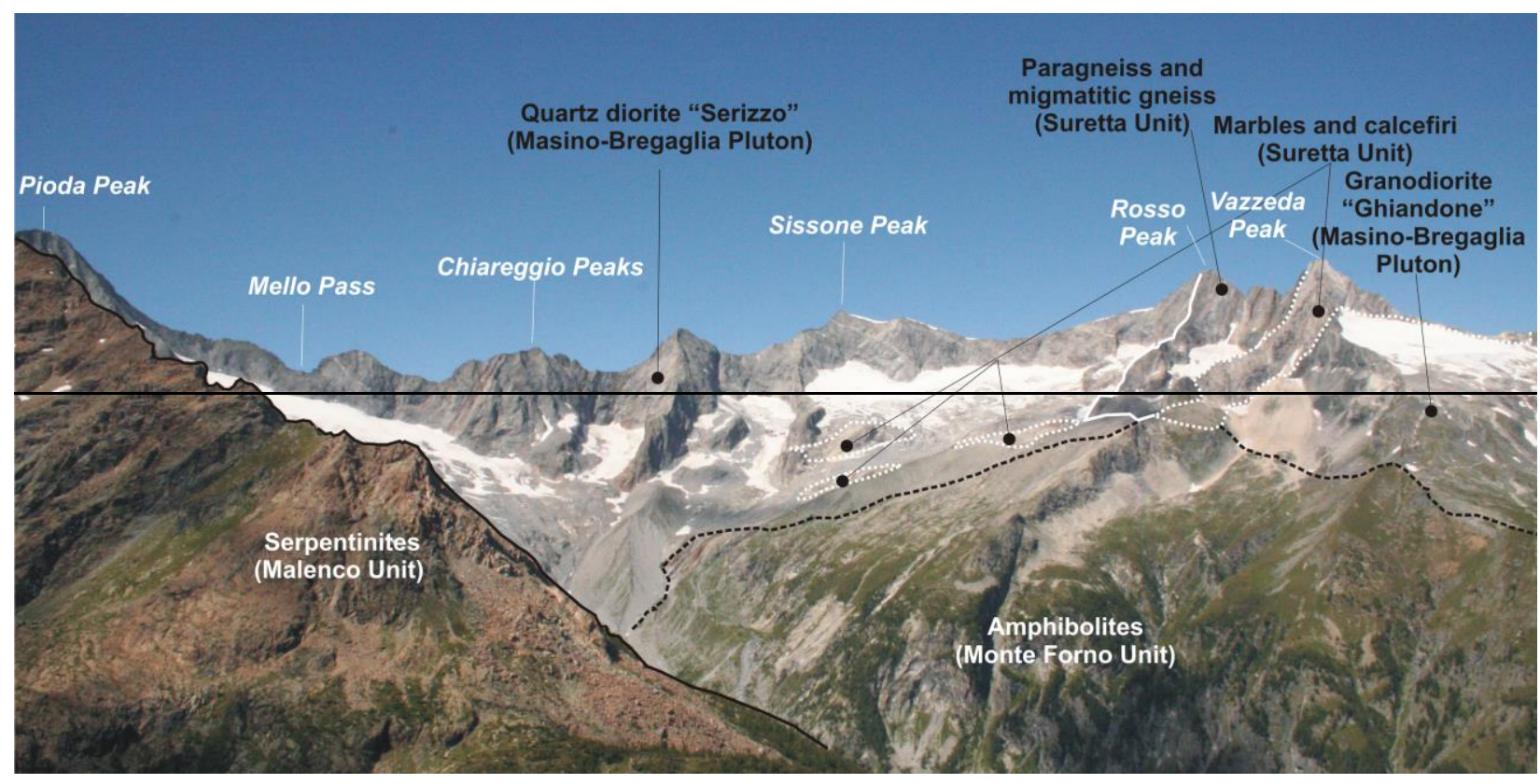

Table 1 Summary table of the described sites and landscapes. The reference code and the scientific interest are from Geoportale Regione Lombardia.

\begin{tabular}{llll}
\hline & Site & Landscape & $\begin{array}{l}\text { Regional Geosites list } \\
\text { Code }\end{array}$ \\
\hline 1 & Forni Glacier & Glacial & SO0034 \\
\hline 2 & Foscagno rock glacier & Periglacial & SO0022 \\
\hline 3 & Val Pola landslide & Rock avalanche & SO0020 \\
\hline 4 & Postalesio earth pyramids & Water runoff on glacial deposits & SO0010 \\
\hline 5 A & Val Masino-Bregaglia granitic pluton & Lithological & SO0009 \\
\hline $5 B$ & Malenco-Forno ophiolitic Unit & Lithological & SO0016 \\
\hline 6 & Lake Como and Pian di Spagna & Lacustrine & CO0015; SO0030 \\
\hline 7 & Karst of the Grigne Massif & Lithological & LC0008 \\
\hline
\end{tabular}

